\title{
Trigger pSA predicting recurrence from positive choline PET/CT with prostate cancer after initial treatment
}

\author{
Junbao Wei ${ }^{1, *}$, Hengzong Zhu ${ }^{2, *}$ and Xiaoli Liao ${ }^{3}$ \\ ${ }^{1}$ Department of Therapeutic Radiology, Guangxi Autonomous Regional Cancer Hospital \& Cancer Hospital of Guangxi Medical \\ University, Nanning, 530021, China \\ ${ }^{2}$ Department of General Medicine, Longan Hospital of Traditional Chinese Medicine, Nanning, 532700, China \\ ${ }^{3}$ The Oncology Department, Guangxi Autonomous Regional Cancer Hospital \& Cancer Hospital of Guangxi Medical University, \\ Nanning, 530021, China \\ *These authors contributed equally to this work
}

Correspondence to: Xiaoli Liao, email: 121021866@qq.com

Keywords: prostate cancer; recurrence; choline PET/CT; PSA; meta-analysis

Received: July 27, 2017 Accepted: December 13, 2017 Epub: January 24, 2018 Published: March 06, 2018

Copyright: Wei et al. This is an open-access article distributed under the terms of the Creative Commons Attribution License 3.0 (CC BY 3.0), which permits unrestricted use, distribution, and reproduction in any medium, provided the original author and source are credited.

\section{ABSTRACT}

Purpose: To assess the relationship between the diagnostic accuracy of Choline positron emission tomography/computed tomography (PET/CT) and the trigger prostate-specific antigen (PSA) level in patients with a biochemical recurrence of prostate cancer.

Materials and Methods: A meta-analysis was conducted to synthesize data across multiple studies.

Results: The pooled sensitivity and specificity of choline PET/CT were $82 \%$ (95\% Confidence Interval (CI):80-84\%) and 92\% (95\%CI: 90-93\%), respectively. The pooled sensitivity and specificity of ${ }^{18} \mathrm{~F}$-choline PET/CT were $81 \%(95 \% \mathrm{CI}$ : 78-84\%) and $90 \%$ (95\%CI: $85-93 \%)$, respectively. The pooled sensitivity and specificity of ${ }^{11} \mathrm{C}$-choline PET/CT were $83 \%$ (95\% CI: $\left.80-86 \%\right)$ and $92 \%(95 \%$ CI: 90-94\%), respectively. The pooled detection rate of ${ }^{18} \mathrm{~F}-\mathrm{ch}$ oline PET/CT and ${ }^{11}$ C-choline PET/CT were 58\% (95\% CI: 48-68\%) and 58\% (95\%CI: 49-68\%), respectively.

Conclusions: Trigger PSA is an important risk factor for positive findings of Choline PET/CT and the detection rate of Choline PET/CT for recurrent prostate cancer increased in parallel with raises in PSA-values. Choline PET/CT got higher detection rate while the trigger $\mathrm{PSA}>\mathbf{2 n g} / \mathrm{ml}$.

\section{INTRODUCTION}

Prostate cancer (PC) ranks second malignant tumor in male in developed world [1]. Radical prostatectomy or radiotherapy has succeeded in treating patients who suffered from localized PC. About $15 \%$ to $77 \%$ of patients suffered PSA relapse within 5 years after initial treatment [2-4]. High-intensity focused ultrasound ablation, brachytherapy, cryotherapy or radical prostatectomy (RP) have been successfully used to treat recurrent tumor, metastasis will occur in 3 years if these treatments are not performed in time $[4,5]$. The most important issue before initial treatment is to identify if the illness is localized or metastasis since PSA relapse is still a clinical dilemma.
However, it is difficult to determine the presence of recurrence, since the specificity and sensitivity for recurrent prostate are poor of traditional imaging approaches such as CT or TRUS [6, 7]. Recently, 18F-choline PET/CT and ${ }^{11} \mathrm{C}$-choline PET/CT have been proved effective for detecting recurrent PC with PSA relapse [4], but the most accurate imaging tracer of choline PET/CT and the relation among diagnostic accuracy of choline PET/CT and trigger PSA are still controversial. The purpose of our study is to evaluate the diagnostic efficiency of choline PET/CT in identifying recurrent $\mathrm{PC}$ and estimate the connection between its diagnostic efficiency and the trigger PSA level in PSA relapse patients. 


\section{RESULTS}

\section{Search results and study selection}

The steps of the literature search and article screening were shown in Figure 1. 456 articles were found after preliminary online searches, 83 articles among them potentially met the inclusive standards after screening abstracts and titles, 39 of them were excluded after we study every full text carefully, the reasons are as follows: (1) The articles was not to demonstrate the diagnostic value of choline PET/CT $(n=26)$; (2) choline was not used as a imaging tracer $(n=5)$; (3) articles didn't provide enough data to identify or calculate TP, FP, $\mathrm{TN}, \mathrm{FN}$ and/or detecting rate $(n=4)$; (4) histopathology and/or clinical and imagine follow up were not used as the reference standard $(n=2)$; (5) without high quality of study design $(n=2)$. After screening, 44 articles [15$21,23-41,43,44,46-61]$ were included in our metaanalysis.

\section{Study characteristics}

Individual study characteristics are presented in Supporting Supplementary Table 1. As some lesion were deeply located and was technically and/or morally difficult to carry out histopathological analysis for all the pathological changes, it is unavoidable to apply histopathology and/or clinical and imaging follow up as reference standard [1].

\section{Data analysis}

Nine sets of data along with eight studies reported the trigger PSA influencing Choline PET/CT detecting rate with PSA relapse PC. Among the nine sets of data, only one articles [21] showed that trigger PSA was not significantly $(P=0.938)$ related with positive choline PET/CT while the others showed significantly $(p<0.05=$ influence. Heterogeneity of selected studies was examined according to the $\mathrm{I}^{2}$ statistic and $p$-value and obvious heterogeneity was found in the nine sets of data $\left(I^{2}=58.8 \%, p=0.013\right)$ with a combined OR of 1.25 (95\%CI, 1.18-1.34) as calculated by the random-effects model. Sensitivity analysis was conducted to explore heterogeneity (Supplementary Figure 1). The major source of heterogeneity was from the data which was based on Mazola's study [20A] including 133 patients. No heterogeneity was found among the other studies when that set of data was excluded $\left(I^{2}=48.7 \%, p\right.$ $=0.058)$. The fixed-effects model was applied to calculate the OR of the remaining seven sets of data and the combined OR was 1.45 (95\% CI, $1.23=1.71$, Figure 2). After a subgroup analysis conducted by tracer, we found a combined OR of $2.21(95 \% \mathrm{CI}, 1.21-4.05)$ with obvious heterogeneity $\left(\mathrm{I}^{2}=58.8 \%, p=0.013\right)$ in ${ }^{18} \mathrm{~F}$-choline PET/ $\mathrm{CT}$, while the combined OR is 1.30 (95\%CI, 1.20-1.41) without heterogeneity $\left(\mathrm{I}^{2}=0 \%, p=0.704\right)$ in C11-choline $\mathrm{PET} / \mathrm{CT}$, both were calculated by the random-effects model (Figure 2).

Across all the 27 included articles with 29 sets of data which provide enough data to identify or calculate TP, FP, TN and FN, specificity, sensitivity, positive/negative predictive value and DOR for each individual study are listed in Supporting Supplementary Table 2. 29 sets of data indicate pool sensitivity and specificity of $82 \%(95 \% \mathrm{CI}$ : $80-84 \%)$ and $92 \%$ (95\% CI 90-93\%), respectively. The forest plots are shown in Figures 3-4. The AUC of choline $\mathrm{PET} / \mathrm{CT}$ is 0.9264 , the $\mathrm{Q}^{*}$ index estimate of is 0.8609 (Supporting Supplementary Figure 2). In a subgroup analysis (Table 1$)$, tracer type $\left({ }^{18} \mathrm{~F}\right.$-choline VS. ${ }^{11} \mathrm{C}$-choline) was compared with specificity, sensitivity, PLR, NLR and DOR, there were no significant differences between the two type of choline PET/CT $(P>0.05)$.

36 articles reported the detecting rate result and the pool detecting rate was $59 \%(95 \%$ CI $51-66 \%)$ with high heterogeneity $\left(p<0.000, I^{2}=96.1 \%\right)$. In a subgroup analysis, the overall detecting rate of $11 \mathrm{C}$-choline PET/CT and $18 \mathrm{~F}-$ Choline PET/CT are $59 \%$ and $58 \%$, respectively (Figures 5-6). Summary detecting rates of two type of Choline PET/CT with different trigger PSA value were showed in Table 2 and Supporting Supplementary Figures 3-18. After corresponding comparing the two type of Choline PET/CT with different PSA thresholds, there were no significant differences between the two type of choline PET/CT $(P>0.05)$.

\section{Quality evaluation}

Each study included in our meta-analysis fulfilled over 8 of the 14 QUADAS criteria for quality evaluation, the quality of the included studies was acceptable (Supporting Supplementary Table 3).

\section{DISCUSSION}

It is critical to identify local or systemic tumor for the treatment of PC patients [29]. PET/CT imaging has become a popular topic recently, but $18 \mathrm{FDG}$ has been proved to be limited value with poor sensitivity $[8,22$, $42,45]$. Recently, some centers also carry out PET/ CT with ${ }^{18} \mathrm{~F}$-choline or ${ }^{\mathrm{C}} 11$-choline radiotracer, the results are still contentious, even there have been several researches reported ${ }^{11} \mathrm{C}$-choline and ${ }^{18} \mathrm{~F}$-choline were promising alternative radiotracers which can provides valuable information not only on local regional but also distant sites of recurrence. These researches also imply a connection between trigger PSA values and imaging sensitivity [2].

Some different studies reported the diagnostic efficiency are still controversial of choline PET/CT detecting recurrence $\mathrm{PC}$. Most of the studies indicates that choline $\mathrm{PET} / \mathrm{CT}$ is accurate in diagnosis recurrence PC $[18,36,20,21]$. However, Vees [37] stated the specificity 
Table 1: Sensitivity, specificity, positive and negative predictive value and DOR of 11C-choline PET/CT and ${ }^{18}$ F-Choline PET/CT

\begin{tabular}{llllll}
\hline Subgroup & $\begin{array}{l}\text { Summary } \\
\text { sensitivity } \\
(\mathbf{9 5 \%} \mathbf{C I})\end{array}$ & $\begin{array}{l}\text { Summary specificity } \\
\mathbf{( 9 5 \%} \mathbf{C I})\end{array}$ & $\begin{array}{l}\text { Summary LR+ } \\
\mathbf{( 9 5 \% ~ C I )}\end{array}$ & $\begin{array}{l}\text { Summary LR- } \\
\mathbf{( 9 5 \% ~ C I ) ~}\end{array}$ & $\begin{array}{l}\text { DOR } \\
\mathbf{( 9 5 \% ~ C I ) ~}\end{array}$ \\
\hline Overall & $0.82(0.80-0.84)$ & $0.92(0.90-0.93)$ & $6.61(3.46-12.61)$ & $0.20(0.14-0.28)$ & $38.55(19.83-74.94)$ \\
${ }^{11} \mathrm{C}-$-choline & $0.83(0.80-0.86)$ & $0.92(0.90-0.94)$ & $8.13(3.95-16.71)$ & $0.21(0.14-0.30)$ & $47.79(25.93-88.10)$ \\
${ }^{18} \mathrm{~F}-$ choline & $0.81(0.78-0.84)$ & $0.90(0.85-0.93)$ & $4.71(1.25-17.82)$ & $0.20(0.10-0.42)$ & $25.78(5.59-118.93)$ \\
$P$ & 0.532 & 0.220 & 0.349 & 0.305 & 0.370 \\
\hline
\end{tabular}

and sensitivity of ${ }^{18} \mathrm{~F}$-choline PET/CT are both poor $(50 \%$ and $43 \%$, respectively). Henninger [34] also got a lower specificity and sensitivity of $57.1 \%$ and $64.3 \%$. For another imaging tracer 11C, Jong [47] and Bertagna [48] informed the sensitivity of $55 \%$ and $60 \%$, respectively; Rinnab [28] and Reske [50] informed the specificity of $36 \%$ and $66.6 \%$, respectively. Across the 28 included articles which can calculate the specificity and sensitivity, a pooled specificity

\section{Articles identified through literature}

search $(\mathrm{n}=456)$

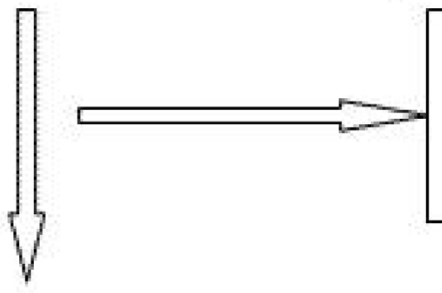

Articles excluded base on screening of titles

and or abstracts using general criteria $(n=373)$

83 potential relevant articles identified for further review

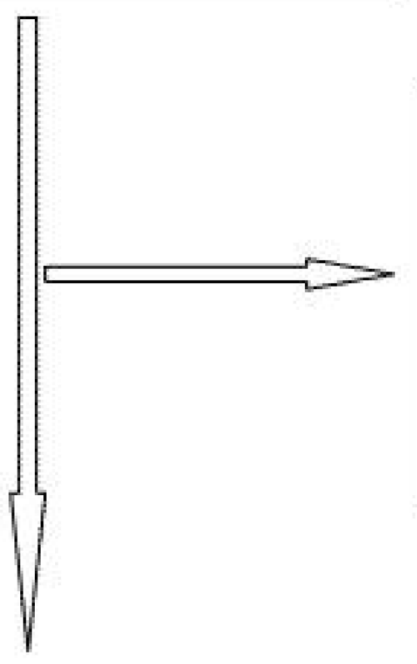

39 articles excluded:

The aim was not to reveal the diagnostic value (26)

Did not use choline as a radiotracer researchers (5)

Without $\mathrm{ORs}$ or $\mathrm{HRS}$, with confidence interval (4)

Without the appropriate reference standard (2)w

Without high quality of study design (2)

44 articles included in analysis

Figure 1: Flow chart for selection of eligible studies. 
Table 2: Detected rate of ${ }^{11} \mathrm{C}$-choline PET/CT and ${ }^{18} \mathrm{~F}-\mathrm{Ch}$-cline PET/CT with different trigger PSA

\begin{tabular}{|c|c|c|c|c|c|c|c|c|c|}
\hline Subgroup & $\begin{array}{c}<0.5 \mathrm{ng} / \mathrm{ml} \\
95 \% \mathrm{CI}\end{array}$ & $\begin{array}{c}<1 \mathrm{ng} / \mathrm{ml} \\
95 \% \mathrm{CI}\end{array}$ & $\begin{array}{c}<1.5 \mathrm{ng} / \mathrm{ml} \\
95 \% \mathrm{CI}\end{array}$ & $\begin{array}{l}>2 \mathrm{ng} / \mathrm{ml} \\
95 \% \mathrm{CI}\end{array}$ & $\begin{array}{c}>3 \mathrm{ng} / \mathrm{ml} \\
95 \% \mathrm{CI}\end{array}$ & $\begin{array}{c}>4 \mathrm{ng} / \mathrm{ml} \\
95 \% \mathrm{CI}\end{array}$ & $\begin{array}{c}>5 \mathrm{ng} / \mathrm{ml} \\
95 \% \mathrm{CI}\end{array}$ & $\begin{array}{c}>10 \mathrm{ng} / \mathrm{ml} \\
95 \% \mathrm{CI}\end{array}$ & $\begin{array}{c}\text { Total } \\
95 \% \mathrm{CI}\end{array}$ \\
\hline \multirow{2}{*}{${ }^{11} \mathrm{C}$-choline } & $8 \%$ & $18 \%$ & $26 \%$ & $73 \%$ & $80 \%$ & $85 \%$ & $69 \%$ & $86 \%$ & $59 \%$ \\
\hline & $1 \%-15 \%$ & $9 \%-28 \%$ & $20 \%-33 \%$ & $63 \%-83 \%$ & $73 \%-88 \%$ & $73 \%-97 \%$ & $54 \%-84 \%$ & $79 \%-94 \%$ & $49 \%-69 \%$ \\
\hline \multirow{2}{*}{${ }^{18} \mathrm{~F}-$ Choline } & $25 \%$ & $39 \%$ & $33 \%$ & $83 \%$ & $80 \%$ & $93 \%$ & $82 \%$ & $84 \%$ & $58 \%$ \\
\hline & $18 \%-32 \%$ & $12 \%-65 \%$ & $25 \%-42 \%$ & $76 \%-90 \%$ & $64 \%-96 \%$ & $84 \%-101 \%$ & $71 \%-93 \%$ & $74 \%-95 \%$ & $48 \%-69 \%$ \\
\hline$P$ & 0.090 & 0.183 & 0.946 & 0.160 & 0.858 & 0.449 & 0.539 & 0.283 & 0.680 \\
\hline
\end{tabular}

and sensitivity of $92 \%(95 \%$ CI $90-93 \%)$ and $82 \%(95 \%$ CI 80-84\%) were found in our Meta-analysis. Our subgroup analysis informed that the pooled sensitivity of ${ }^{18} \mathrm{~F}$-choline $\mathrm{PET} / \mathrm{CT}$ and C11-choline PET/CT are $81 \%$ and $83 \%$, respectively; the pooled specificity of ${ }^{18} \mathrm{~F}$-choline PET/CT and $\mathrm{C} 11$-choline PET/CT are $90 \%$ and $92 \%$, respectively. Because no significant differences were found in specificity, sensitivity, NLR, PLR and DOR between them, they have no obvious difference in detecting recurrent $\mathrm{PC}$.

In our study, Choline PET/CT has good diagnostic accuracy on detecting recurrent $\mathrm{PC}$ across the 28 included articles which can calculate the sensitivity and specificity, on the contrary, the overall detecting rate was only $59 \%$ in 37 included studies which can calculate the detection rate, in the subgroup analysis, the overall detecting rate of ${ }^{18} \mathrm{~F}$-choline PET/CT and $\mathrm{C} 11$-choline PET/CT are $58 \%$ and $59 \%$, respectively. Eight studies along with nine sets of data reported the trigger PSA influencing Choline $\mathrm{PET} / \mathrm{CT}$ detecting rate with PSA relapse PC. Only one article [21] showed that trigger PSA was not an important influence factor for positive findings of Choline PET/CT $(\mathrm{OR}=1.182,95 \% \mathrm{CI}: 0.017-82.774, P=0.938)$ while the

\section{Study}

ID

OR $(95 \% \mathrm{Cl})$

$\%$

Weight

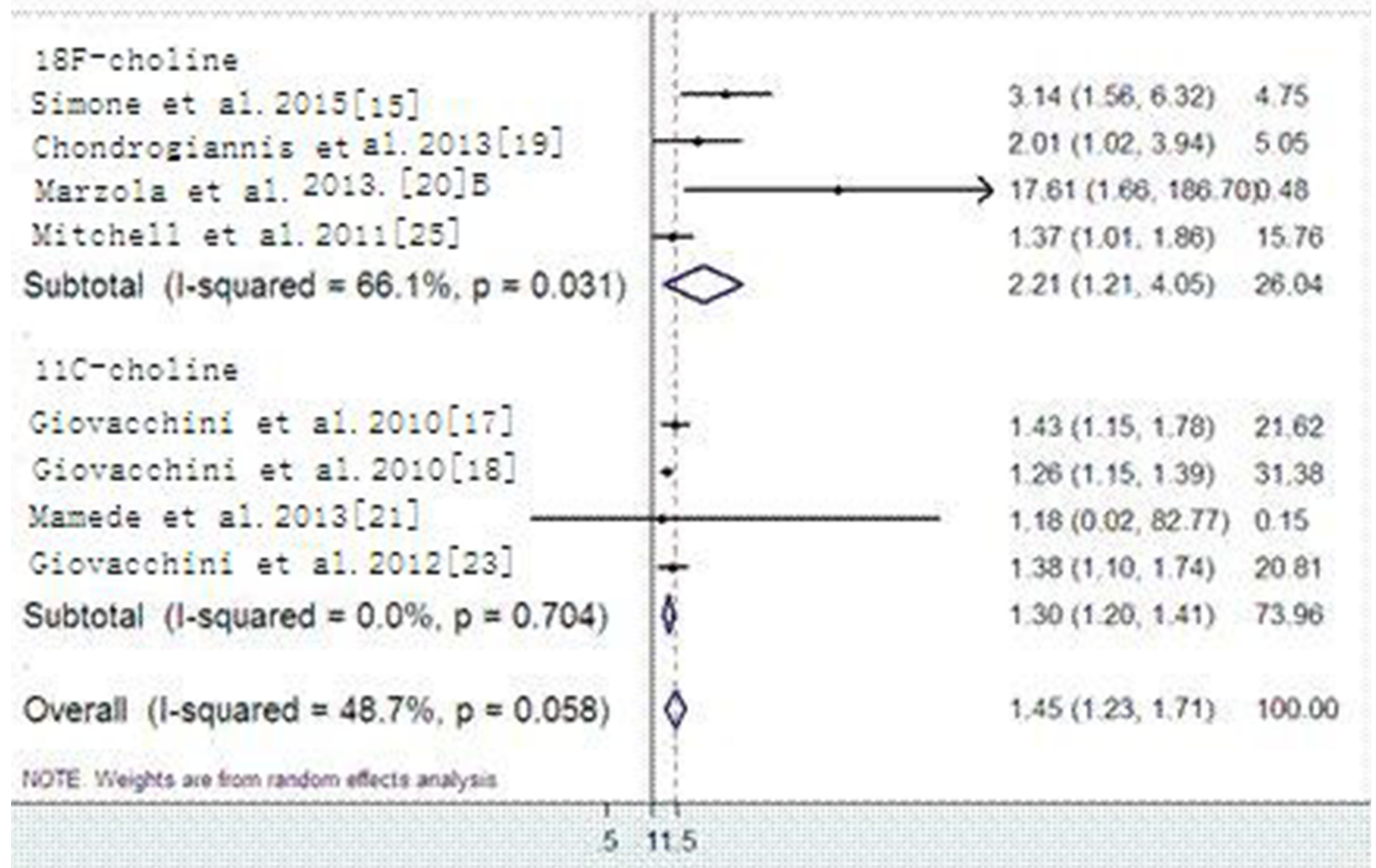

Figure 2: Forest plots of trigger PSA influencing 18F-choline PET/CT and C11-choline PET/CT detection rate (with subgroup analysis). 
others got the contrary result. A combined OR of 1.25 for trigger PSA predicting recurrence from choline PET/CT positive findings with biochemical failure prostate cancer after initial treatment was found in our meta-analysis, after a subgroup analysis, the combined OR were 2.21 and 1.45 in ${ }^{18} \mathrm{~F}$-choline and ${ }^{\mathrm{C}} 11$-choline $\mathrm{PET} / \mathrm{CT}$, respectively. This overall low detection rate is because of a correlation between trigger PSA and the Choline PET/CT detecting rate, a higher trigger PSA value means a higher positive rate of choline $\mathrm{PET} / \mathrm{CT}$.

However, not so much data is available on Choline PET/CT detecting rate for the patients who suffered PSA relapse with lower PSA values [3]. Krause's result
$[2,50]$ showed a detecting rate of recurrence of $56 \%$ of ${ }^{11} \mathrm{C}$-choline PET/CT while the mean PSA is $5.9 \mathrm{ng} /$ $\mathrm{ml}$. They also reported a linear relationship between detecting rate and trigger PSA: the detecting rate are $36 \%, 43 \%, 62 \%$ and $73 \%$ while the PSA value are $<1 \mathrm{ng} / \mathrm{ml}, 1$ to $2 \mathrm{ng} / \mathrm{ml}, 2$ to $3 \mathrm{ng} / \mathrm{ml}$ and $>3 \mathrm{ng} / \mathrm{ml}$, respectively. With the same imaging tracer of $11 \mathrm{C}$ when the trigger PSA $<1.5 \mathrm{ng} / \mathrm{ml}$, Castellucci and Rannab reported the large difference detecting rates of $21 \%$ and $53.8 \%$, respectively [5]. With the other imaging tracer of ${ }^{18} \mathrm{~F}$ when the trigger PSA $<1 \mathrm{ng} / \mathrm{ml}$, Simone and Schillaci reported the large difference detecting rates of $76 \%$ and $20 \%$, respectively $[15,31]$.

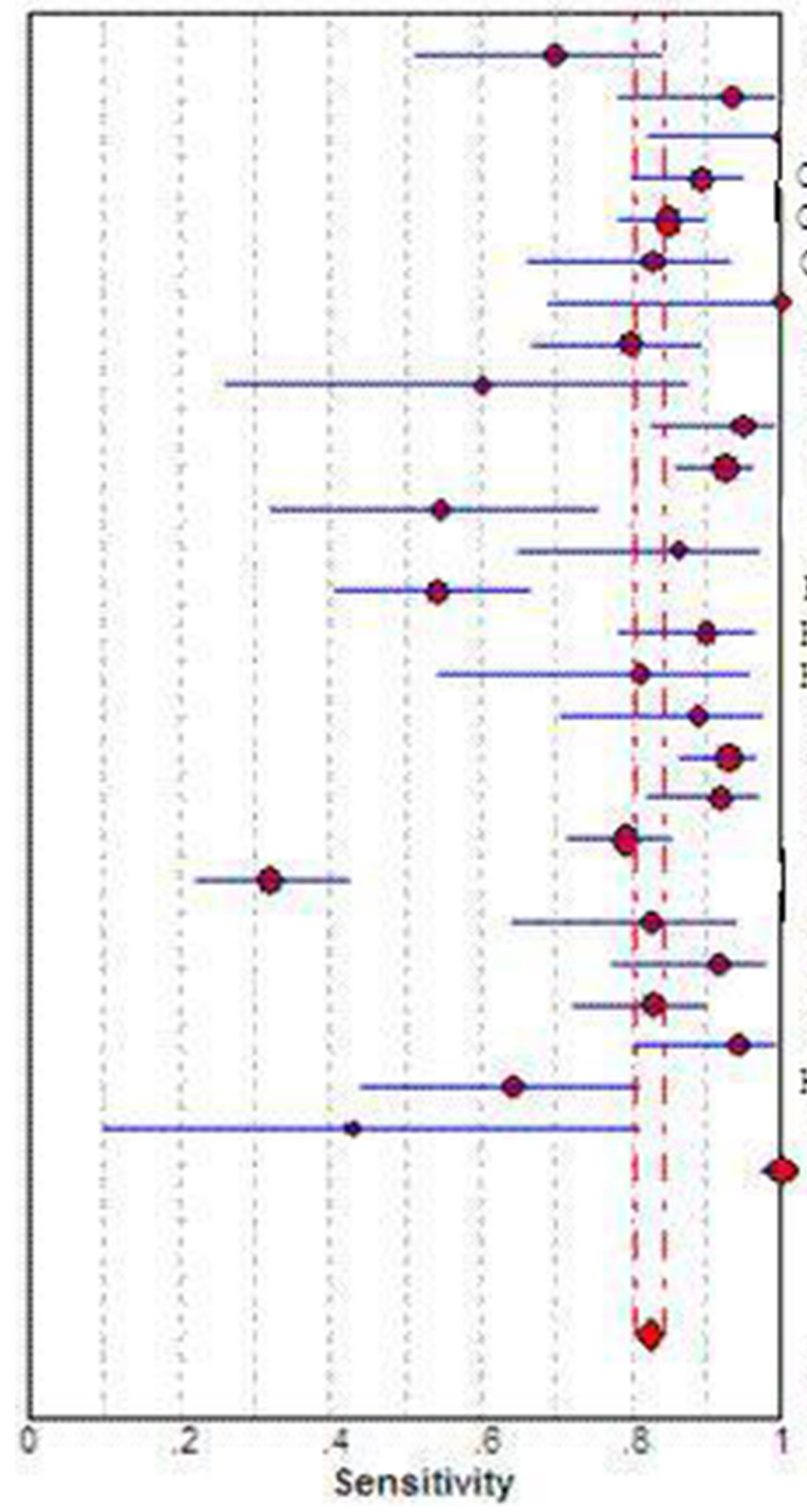

Sensitivity $(95 \% \mathrm{CI})$

Sven N et a1. $2006[26] \quad 0.70 \quad(0.51-0.84)$

Rinnab et a.. 2009[28. _ $0.94 \quad(0.79-0.99)$

Scattoni et a1.2007[30] $1.00 \quad(0.82-1.00)$

Giovachini et a1. $2010[17] 0.89 \quad(0.80 \cdot 0.95)$

Giovachini et al 20:0 1.8 . $0.85(0.79-0.90)$

Castelucoi et al 20:1[34] $0.83(0.66 \cdot 0.93)$

Jong et al. 2008[36] $\quad 1.00 \quad(0.69-1.00)$

Piochio et al. 2003[37] $0.80 \quad(0.67-0.90)$

Bertagna et a1.2011 (38」) $0.60 \quad(0.28-0.88)$

Rinnab et a1. $2007[39] \quad 0.95 \quad(0.83 \cdot 0.99)$

Ceoi et a1. 20:4.41] $\quad 0.92 \quad(0.86 \cdot 0.96)$

Jong et a.. 2003[42] $0.55 \quad(0.32 \cdot 0.76)$

Fucoio et al. 2010[43] $0.86 \quad(0.65-0.97)$

Kitailma et ai. $20: 4[44]$ A $0.54 \quad(0.41-0.67)$

Kitajima et a1. 20:4.44.B $0.90 \quad(0.78-0.97)$

Ritajima et a1. 2014.44.J $0.81 \quad(0.54-0.96)$

Piochio et al. 20:2 .46] $0.89 \quad(0.71-0.98)$

Xitche11 et a1. 2013[25] $0.93 \quad(0.87 \cdot 0.97)$

Husarik et a1. 2008[47] $0.82 \quad(0.82-0.97)$

Simone et a1. 2015[:15] $0.79 \quad(0.72 \cdot 0.86)$

schoder et al. 2005[27] $0.32 \quad(0.22-0.43)$

Pelosi et a1. 2008 [29] $0.83 \quad(0.64 * 0.94)$

Schilaci et a1. 20:2[31] $0.92(0.73-0.98)$

Panebianco et a1. $2012\left[\begin{array}{lll}32 & 0.83 & (0.73-0.91\end{array}\right)$

Yamede et a:. $20: 3[2:], 0.94 \quad(0.80-0.98)$

Henninger et a1. 2012[33] $0.64 \quad(0.44-0.81)$

Vees et a1. 2007 [35] $0.43 \quad(0.10-0.82)$

Yarzola et a1. $2009\left[20^{\circ} \quad 1.00 \quad(0.97-1.00)\right.$

Pocled Sensitivity $=0.82(0.80$ to 0.84$)$

Chi-square $=269.89: 0 t=27(0=0.0000)$

Inconsistency (l-square) $=90.0 \%$

Figure 3: Forest plot of pooled sensitivity of choline PET/CT. 
In our meta-analysis, the pooled detecting rate of $11 \mathrm{C}$-choline PET/CT are $8 \%, 18 \%$ and $26 \%$ while the trigger PSA are $<0.5 \mathrm{ng} / \mathrm{ml},<1 \mathrm{ng} / \mathrm{ml}$ and $<1.5 \mathrm{ng} / \mathrm{ml}$, respectively. The pooled detecting rate of $18 \mathrm{~F}$-choline $\mathrm{PET} / \mathrm{CT}$ are $25 \%, 39 \%$ and $33 \%$ while the trigger PSA are $<0.5 \mathrm{ng} / \mathrm{ml},<1 \mathrm{ng} / \mathrm{ml}$ and $<1.5 \mathrm{ng} / \mathrm{ml}$, respectively. For all lower PSA values, the detecting efficiency of the two type of C-choline PET/CT are both lower. While the trigger PSA improve to $>2 \mathrm{ng} / \mathrm{ml},>3 \mathrm{ng} / \mathrm{ml},>4 \mathrm{ng} / \mathrm{ml}$, $>5 \mathrm{ng} / \mathrm{ml}$ and $>10 \mathrm{ng} / \mathrm{ml}$, the pooled detecting rate of ${ }^{\mathrm{C}} 11$-choline PET/CT are $73 \%, 80 \%, 85 \%, 69 \%$ and $86 \%$, respectively, the pooled detecting rate of ${ }^{18} \mathrm{~F}$-choline PET/ CT are $83 \%, 80 \%, 93 \%, 82 \%$ and $84 \%$, respectively. For all higher PSA values, the detecting efficiency of the two type of C-choline PET/CT are both higher. In that case, the linear relationship doesn't exist between trigger PSA and detecting rate when the trigger level $>2 \mathrm{ng} / \mathrm{ml}$.
Our study still has some limitations. Just like all the meta-analysis of diagnostic accuracy, our study is also restricted by the degree of heterogeneity which consists of methodological quality, radiologist experience and approach to image interpretation. We deal with the heterogeneity issue in 3 ways: (1) Strict inclusive criteria were used to minimize diversity while selecting studies, (2) Provided objective and rigorous evaluating of quality of included articles by a validated tool (QUADAS), (3) Performed stratified analysis base on the factors that probably lead to heterogeneity. Another limitation is that there is no acceptable gold standard, which is general weakness of most studies researching different tumors and various imaging modality for diagnostic efficiency in the diagnosing recurrent lesions. As the lesion were deeply located and was technically and morally difficult to carry out histopathological analysis for all the pathological changes,

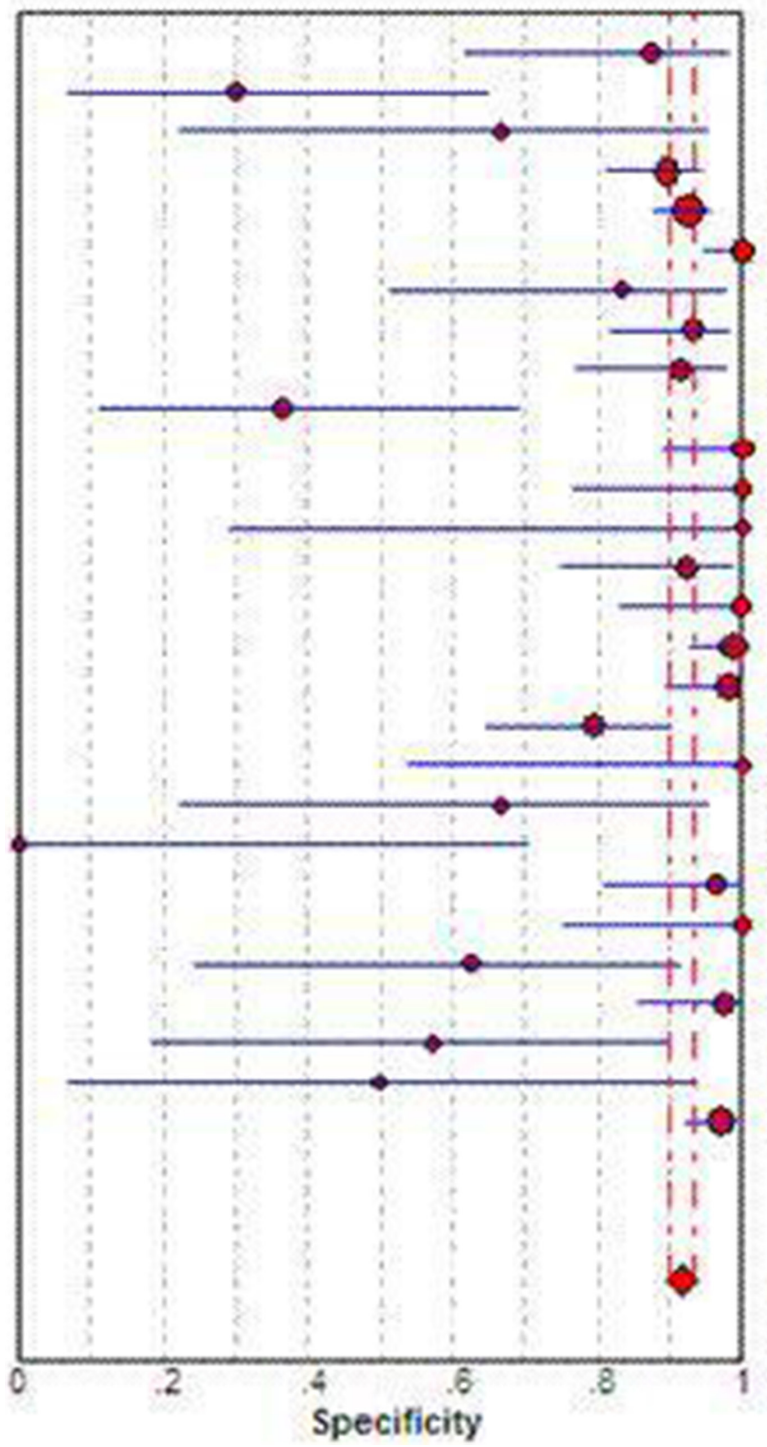

Specificity $(95 \% \mathrm{Cl})$

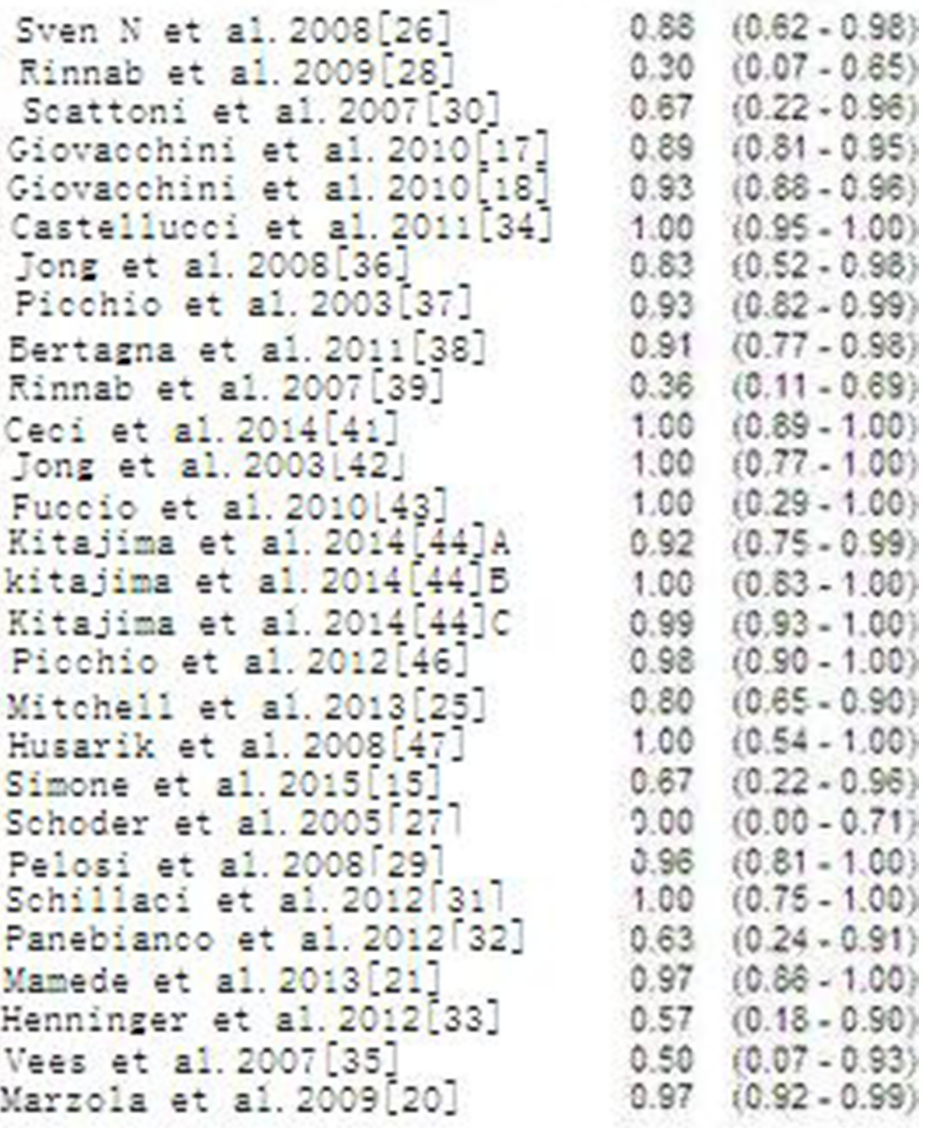

Pooled Specificty $=0.92(0.90$ to 0.93$)$

Chi-square $=136.64 ;$ ot $=27(0=0.0000)$

Inconsistency (-square) $=80.2 \%$

Figure 4: Forest plot of pooled specificity of choline PET/CT. 
it is unavoidable to apply histopathology and/or clinical and imaging follow up as reference standard, therefore there is a chance for verification bias [1]. At last, heterogeneity also can due to some unreported or unmeasured study features, which is inherent to a meta-analysis based on published data.

\section{MATERIALS AND METHODS}

\section{Search strategy and definitions}

\section{Data extraction and quality assessment}

The following data were collected from each publication: the name of the first author, year of publication, study design, No. of patients, PSA level, initial treatment type, reference standard used, criteria used to define the cut-off between positive and negative on choline PET/ CT, sensitivity, specificity, PPV, NPV, overall accuracy, detection rate and ORs or HRs with confidence interval. Sensitivity and specificity were used when the standards of reference for discriminating true from false findings were pathological findings and/or a composite yet acceptable surrogate including other imaging methods (CT, MR, BS), clinical follow-up for at least 12 months, including repeated $\mathrm{CT}, \mathrm{MR}, \mathrm{BS}$ and choline PET/CT revealing the appearance of further metastatic lesions, or the disappearance of metastatic lesions associated with normalization of PSA values $(<0.2 \mathrm{ng} / \mathrm{ml})$ following systemic therapy. Detection rate was defined as the number of subjects positive on choline PET/CT in relation to the overall number of subjects

\section{Study}

ID

ES $(95 \% \mathrm{Cl})$

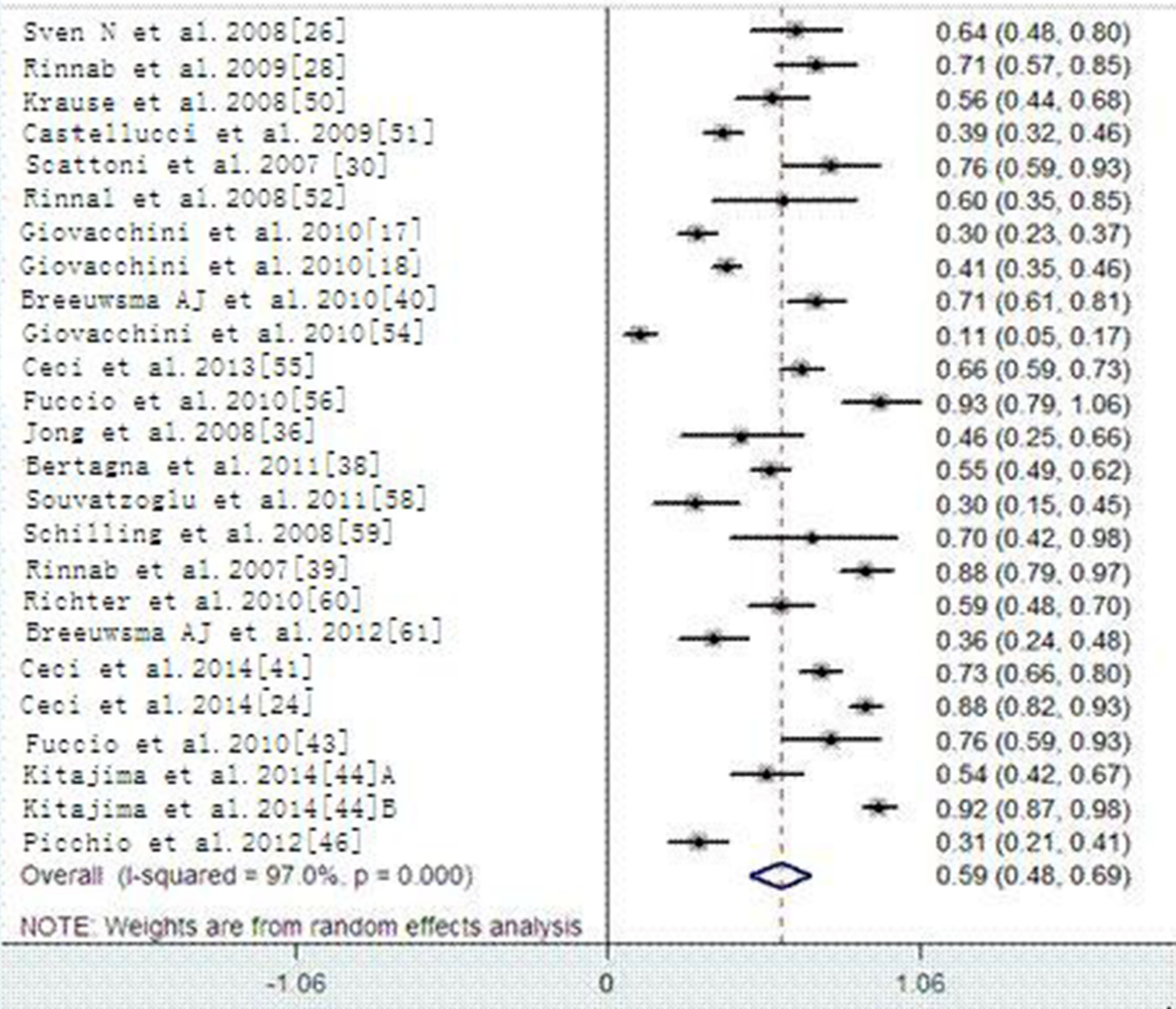

Figure 5: Detected rate of 11C-Choline PET/CT. 
included in the study and Detection rate was used when the examinations used as the standard of reference including other imaging methods were carried out at the same time as the index examination. The OR was assumed to be the same as HR, and all results are reported as OR for simplicity [8]. Concerning to the quality of study design, study quality was assessed with the QUADAS checklist for studies of diagnostic accuracy included in systematic reviews [9], only the article in which the number of the answer 'yes' for the 14 questions in QUADAS quality assessment tool was larger than 9 was included.

\section{Statistical analysis}

Statistical heterogeneity among studies was assessed using the chi-square test (results were defined as heterogeneous for a $P$ value $<0.10$ ), and the potential inconsistency was quantified through the I2 statistic, which describes the percentage of total variation across studies that is due to heterogeneity rather than chance [10]. $\mathrm{P}<0.05$ was considered as having apparent heterogeneity for chi-squared tests and a random effect model was used for the primary meta-analysis to obtain summary estimates with $95 \%$ confidence intervals if heterogeneity existed.

For the articles which provide data that could be used to construct or calculate true-positive, falsepositive, true-negative, and/or false-negative results, we calculated pooled specificity and pooled sensitivity for each modality. A value of 0.5 was added to all cells of studies that contained a count of zero to avoid potential problems in odds calculations for studies with specificities or sensitivities of $100 \%$. Likelihood ratios (LR) are metrics that combine both specificity and sensitivity in their calculation. LR- is defined as the ratio of (1sensitivity) over specificity whereas LR + is defined as the ratio of sensitivity over (1- specificity). Both LRs equal 1 when there is absolutely no discriminating ability for a diagnostic test. Although there is no absolute standard, a good diagnostic test may have LR+ greater than 5.0 and LR- less than 0.2 [11]. Since the area under the ROC curve (AUC) was used as an alternative global measure of test performance [12], we also used the derived estimates of sensitivity, specificity and respective variances to construct a summary receiver operating characteristic (ROC) curve

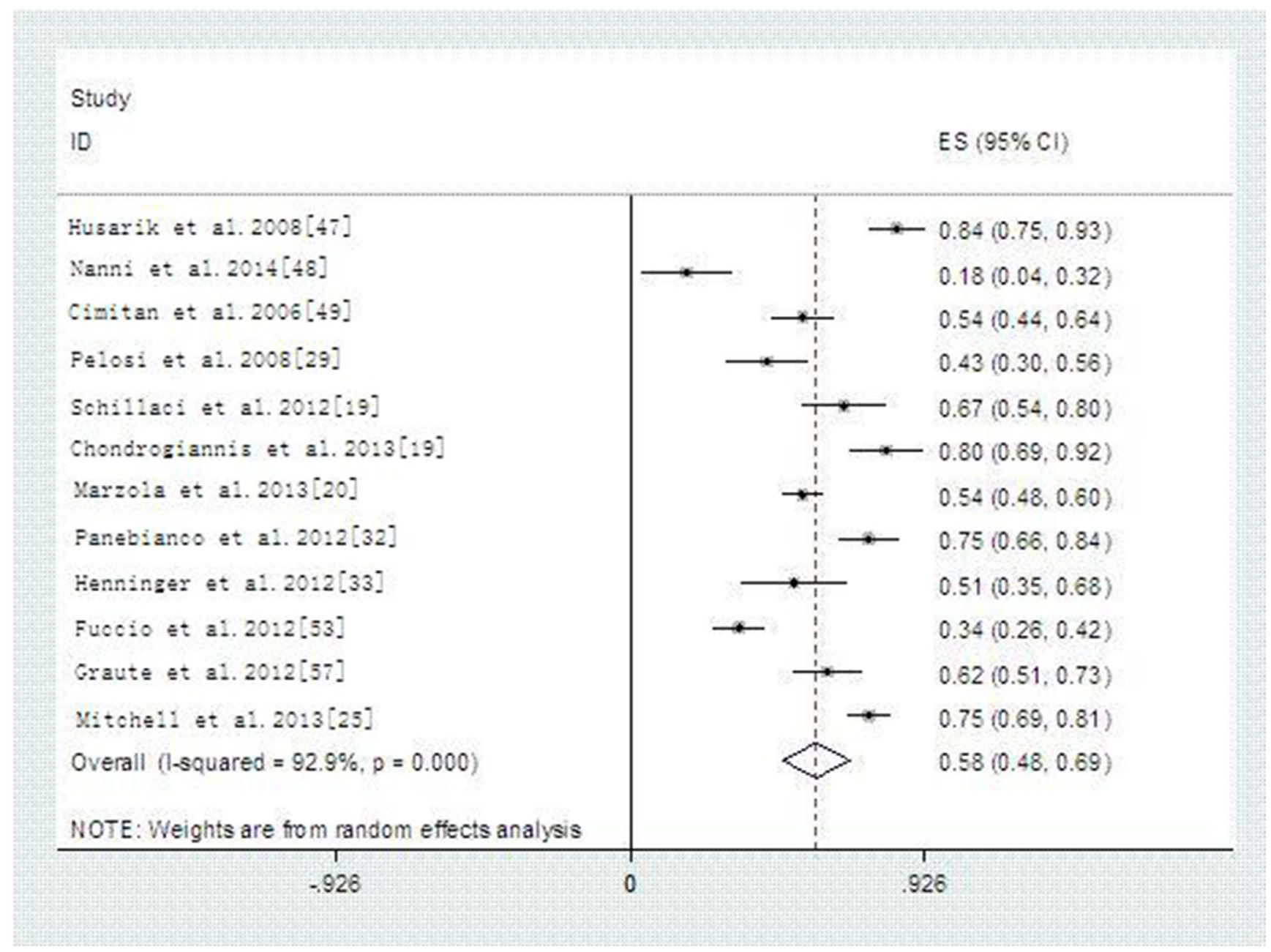

Figure 6: Detected rate of 18F-Choline-PET/CT. 
and the $\mathrm{Q}^{*}$ index. Then we $\operatorname{did} \mathrm{Z}$ test to find whether the sensitivity, specificity and DOR and of ach technique were significantly different from the others. If $P<0.05$, the result was considered to be statistically significant.

For the articles which provide ORs or HRs with confidence interval, if the heterogeneity was acceptable $\left(\mathrm{I}^{2}<\right.$ $50 \%$ ), a fixed effects analysis was conducted to calculate the pooled OR. In addition, a random effects model was used. The causes of heterogeneity were investigated by subgroup analyses. The detection rates were pooled using the generic inverse variance approach in the random-effects model [13].

Publication bias was assessed by using a scatter plot of the inverse of the square root of the effective sample size (ESS1/2) versus the diagnostic log odds ratio visually, which would have a symmetric funnel shape when publication bias was absent. Formal testing for publication bias was conducted by using a regression of the diagnostic log odds ratio against ESS1/2 and weighting according to the effective sample size, with $P<0.05$ indicating significant asymmetry [14]. All statistical tests were 2-sided.

\section{CONCLUSIONS}

$18 \mathrm{~F}$ and $11 \mathrm{C}$ choline PET/CT are accurate to diagnose recurrent lesion in PSA relapse patients for $\mathrm{PC}$, their diagnostic efficiency was not significantly different. Trigger PSA is an important influence factor for positive findings of Choline PET/CT, the detecting rate getting higher in parallel with raises in PSA values. Choline PET/CT got higher detecting rate while the trigger PSA $>2 \mathrm{ng} / \mathrm{ml}$.

\section{Ethical approval}

This article does not contain any studies with human participants or animals performed by any of the authors. This is a diagnostic study.

\section{Disclosure}

The scientific guarantor of this publication is Chunhua Wu. The authors of this manuscript declare no relationships with any companies, whose products or services may be related to the subject matter of the article. The authors state that this work has not received any funding. No complex statistical methods were necessary for this paper.

\section{CONFLICTS OF INTEREST}

There are no potential conflicts of interest, and there are no fund sources for the financial support.

\section{FUNDING}

No funding was received.

\section{REFERENCES}

1. Jemal A, Center MM, DeSantis C, Ward EM. Global patterns of cancer incidence and mortality rates and trends. Cancer Epidemiol Biomarkers Prev. 2010; 19:1893-907.

2. Dillioglugil O, Leibman BD, Kattan MW, Seale-Hawkins C, Wheeler TM, Scardino PT. Hazard rates for progression after radical prostatectomy for clinically localized prostate cancer. Urology. 1997; 50:93-9.

3. Pound CR, Partin AW, Eisenberger MA, Chan DW, Pearson JD, Walsh PC. Natural history of progression after PSA elevation following radical prostatectomy. JAMA. 1999; 281:1591-7.

4. Lee WR, Hanks GE, Hanlon A. Increasing prostate-specific antigen profile following definitive radiation therapy for localised prostate cancer: clinical observations. J Clin Oncol. 1997; 15:230-8.

5. Bianco FJ Jr, Scardino PT, Stephenson AJ, Diblasio CJ, Fearn PA, Eastham JA. Long-term oncologic results of salvage prostatectomy for locally recurrent prostate cancer after radiotherapy. Int J Radiat Oncol Biol Phys. 2005; 62:448-53.

6. Roach M. The role of PSA in the radiotherapy of prostate cancer. Oncology. 1996; 10:1143-53.

7. Mottet N, Bellmunt J, Bolla M, Joniau S, Mason M, Matveev V, Schmid HP, Van der Kwast T, Wiegel T, Zattoni F, Heidenreich A. EAU guidelines on prostate cancer. Part II: treatment of advanced, relapsing, and castration-resistant prostate cancer. Eur Urol. 2011; 59:572-83.

8. Wells GA, Shea B, O'Connell D, Peterson J, Welch V, Losos M, Tugwell P. The Newcastle-Ottawa Scale (NOS) for assessing the quality of nonrandomised studies in the meta-analysis. 2011. Available from: http://www.ohri.ca/ programs/clinical_epidemiology/oxford.asp.

9. Greenland S. Quantitative methods in the review of epidemiologic literature. Epidemiol Rev. 1987; 9:1-30.

10. DerSimonian R, Laird N. Meta-analysis in clinical trials. Control Clin Trials. 1986; 7:177-88.

11. Pakos EE, Kyzas PA, Ioannidis JP. Prognostic significance of TP53 tumor suppressor gene expression and mutations in human osteosarcoma: a metaanalysis. Clin Cancer Res. 2004; 10:6208-14.

12. Higgins JP, Thompson SG, Deeks JJ, Altman DG. Measuring inconsistency in meta-analyses. BMJ. 2003; 327:557-60.

13. Begg CB, Mazumdar M. Operating characteristics of a rank correlation test for publication bias. Biometrics. 1994; 50:1088-101.

14. Egger M, Smith GD. Bias in location and selection of studies. BMJ. 1998; 316:61-6.

15. Simone G, Di Pierro GB, Papalia R, Sciuto R, Rea S, Ferriero M, Guaglianone S, Maini CL, Gallucci M. Significant increase in detection of prostate cancer recurrence following radical prostatectomy with an early 
imaging acquisition protocol with $18 \mathrm{~F}$-fluorocholine positron emission tomography/computed tomography. World J Urol. 2015; 33:1511-8.

16. Giovacchini G, Picchio M, Garcia-Parra R, Mapelli P, Briganti A, Montorsi F, Gianolli L, Messa C. [11C] choline positron emission tomography/computerized tomography for early detection of prostate cancer recurrence in patients with low increasing prostate specific antigen. J Urol. 2013; 189:105-10.

17. Giovacchini G, Picchio M, Scattoni V, Garcia Parra R, Briganti A, Gianolli L, Montorsi F, Messa C. PSA doubling time for prediction of [11C] choline PET/CT findings in prostate cancer patients with biochemical failure after radical prostatectomy. Eur J Nucl Med Mol Imaging. 2010; 37:1106-16.

18. Giovacchini G, Picchio M, Coradeschi E, Bettinardi V, Gianolli L, Scattoni V, Cozzarini C, Di Muzio N, Rigatti P, Fazio F, Messa C. Predictive factors of [11. C] choline $\mathrm{PET} / \mathrm{CT}$ in patients with biochemical failure after radical prostatectomy. Eur J Nucl Med Mol Imaging. 2010; 37:301-9.

19. Chondrogiannis S, Marzola MC, Ferretti A, Maffione AM, Rampin L, Grassetto G, Nanni C, Colletti PM, Rubello D. Role of $18 \mathrm{~F}$-choline PET/CT in suspicion of relapse following definitive radiotherapy for prostate cancer. Eur J Nucl Med Mol Imaging. 2013; 40:1356-64.

20. Marzola MC, Chondrogiannis S, Ferretti A, Grassetto G, Rampin L, Massaro A, Castellucci P, Picchio M, AlNahhas A, Colletti PM, Marcolongo A, Rubello D. Role of $18 \mathrm{~F}$-choline PET/CT in biochemically relapsed prostate cancer after radical prostatectomy: correlation with trigger PSA, PSA velocity, PSA doubling time, and metastatic distribution. Clin Nucl Med. 2013; 38:e26-32.

21. Mamede M, Ceci F, Castellucci P, Schiavina R, Fuccio C, Nanni C, Brunocilla E, Fantini L, Costa S, Ferretti A, Colletti PM, Rubello D, Fanti S. The role of 11C-choline PET imaging in the early detection of recurrence in surgically treated prostate cancer patients with very low PSA level < 0.5 ng/mL. Clin Nucl Med. 2013; 38:e342-5.

22. Salminen E, Hogg A, Binns D, Frydenberg M, Hicks R. Investigations with FDG-PET scanning in prostate cancer show limited value for clinical practice. Acta Oncol. 2002; 41:425-9.

23. Giovacchini G, Picchio M, Parra RG, Briganti A, Gianolli L, Montorsi F, Messa C. Prostate-specific antigen velocity versus prostate-specific antigen doubling time for prediction of $11 \mathrm{C}$ choline PET/CT in prostate cancer patients with biochemical failure after radical prostatectomy. Clin Nucl Med. 2012; 37:325-31.

24. Ceci F, Castellucci P, Graziani T, Schiavina R, Brunocilla E, Mazzarotto R, Ntreta M, Lodi F, Martorana G, Fanti S. 11C-choline PET/CT detects the site of relapse in the majority of prostate cancer patients showing biochemical recurrence after EBRT. Eur J Nucl Med Mol Imaging. 2014; 41:878-86.
25. Mitchell CR, Lowe VJ, Rangel LJ, Hung JC, Kwon ED, Karnes RJ. Operational characteristics of (11. c-choline positron emission tomography/computerized tomography for prostate cancer with biochemical recurrence after initial treatment. J Urol. 2013; 189:1308-13.

26. Reske SN, Blumstein NM, Glatting G. [11C] choline PET/CT imaging in occult local relapse of prostate cancer after radical prostatectomy. Eur J Nucl Med Mol Imaging. 2008; 35:9-17.

27. Schöder H, Herrmann K, Gönen M, Hricak H, Eberhard S, Scardino P, Scher HI, Larson SM. 2-[18F]fluoro-2deoxyglucose positron emission tomography for the detection of disease in patients with prostate-specific antigen relapse after radical prostatectomy. Clin Cancer Res. 2005; 11:4761-9.

28. Rinnab L, Simon J, Hautmann RE, Cronauer MV, Hohl K, Buck AK, Reske SN, Mottaghy FM. [(11. C]choline PET/ $\mathrm{CT}$ in prostate cancer patients with biochemical recurrence after radical prostatectomy. World J Urol. 2009; 27:619-25.

29. Pelosi E, Arena V, Skanjeti A, Pirro V, Douroukas A, Pupi A, Mancini M. Role of whole-body 18 F-choline PET/CT in disease detection in patients with biochemical relapse after radical treatment for prostate cancer. Radiol Med. 2008; 113:895-904.

30. Scattoni V, Picchio M, Suardi N, Messa C, Freschi M, Roscigno M, Da Pozzo L, Bocciardi A, Rigatti P, Fazio F. Detection of lymph-node metastases with integrated [11C] choline PET/CT in patients with PSA failure after radical retropubic prostatectomy: results confirmed by open pelvicretroperitoneal lymphadenectomy. Eur Urol. 2007; 52:423-9.

31. Schillaci O, Calabria F, Tavolozza M, Caracciolo CR, Finazzi Agrò E, Miano R, Orlacchio A, Danieli R, Simonetti G. Influence of PSA, PSA velocity and PSA doubling time on contrast-enhanced $18 \mathrm{~F}$-choline PET/CT detection rate in patients with rising PSA after radical prostatectomy. Eur J Nucl Med Mol Imaging. 2012; 39:589-96.

32. Panebianco V, Sciarra A, Lisi D, Galati F, Buonocore V, Catalano C, Gentile V, Laghi A, Passariello R. Prostate cancer: 1 HMRS-DCEMR at 3 T versus $[(18 . \mathrm{F}]$ choline PET/ $\mathrm{CT}$ in the detection of local prostate cancer recurrence in men with biochemical progression after radical retropubic prostatectomy (RRP). Eur J Radiol. 2012; 81:700-8.

33. Henninger B, Vesco P, Putzer D, Kendler D, Loizides A, Bale RJ, Virgolini IJ. [18F]choline positron emission tomography in prostate cancer patients with biochemical recurrence after radical prostatectomy: influence of antiandrogen therapy - a preliminary study. Nucl Med Commun. 2012; 33:889-94.

34. Castellucci P, Fuccio C, Rubello D, Schiavina R, Santi I, Nanni C, Allegri V, Montini GC, Ambrosini V, Boschi S, Martorana G, Marzola MC, Fanti S. Is there a role for ${ }^{11} \mathrm{C}$-choline PET/CT in the early detection of metastatic disease in surgically treated prostate cancer patients with a mild PSA increase < $1.5 \mathrm{ng} / \mathrm{ml}$ ? Eur J Nucl Med Mol Imaging. 2011; 38:55-63.

35. Vees H, Buchegger F, Albrecht S, Khan H, Husarik D, Zaidi H, Soloviev D, Hany TF, Miralbell R. 18F-choline 
and/or 11C-acetate positron emission tomography: detection of residual or progressive subclinical disease at very low prostate-specific antigen values $(<1 \mathrm{ng} / \mathrm{mL}$. after radical prostatectomy. BJU Int. 2007; 99:1415-20.

36. de Jong IJ, Pruim J, Elsinga PH, Vaalburg W, Mensink HJ. 11C-choline positron emission tomography for the evaluation after treatment of localized prostate cancer. Eur Urol. 2003; 44:32-8.

37. Picchio M, Messa C, Landoni C, Gianolli L, Sironi S, Brioschi M, Matarrese M, Matei DV, De Cobelli F, Del Maschio A, Rocco F, Rigatti P, Fazio F. Value of $[11 \mathrm{C}]$ choline-positron emission tomography for re-staging prostate cancer: a comparison with $[18 \mathrm{~F}]$ fluorodeoxyglucose-positron emission tomography. J Urol. 2003; 169:1337-1340.

38. Bertagna F, Abuhilal M, Bosio G, Simeone C, Rossini P, Pizzocaro C, Orlando E, Finamanti M, Biasiotto G, Rodella C, Cosciani Cunico S, Giubbini R. Role of ${ }^{11} \mathrm{C}$-choline positron emission tomography/computed tomography in evaluating patients affected by prostate cancer with suspected relapse due to prostate-specific antigen elevation. Jpn J Radiol. 2011; 29:394-404.

39. Rinnab L, Mottaghy FM, Blumstein NM, Reske SN, Hautmann RE, Hohl K, Möller P, Wiegel T, Kuefer R, Gschwend JE. Evaluation of [11C]-choline positronemission/computed tomography in patients with increasing prostate-specific antigen levels after primary treatment for prostate cancer. BJU Int. 2007; 100:786-93.

40. Breeuwsma AJ, Pruim J, van den Bergh AC, Leliveld AM, Nijman RJ, Dierckx RA, de Jong IJ. Detection of local, regional, and distant recurrence in patients with psa relapse after external-beam radiotherapy using (11. C-choline positron emission tomography. Int J Radiat Oncol Biol Phys. 2010; 77:160-4.

41. Ceci F, Herrmann K, Castellucci P, Graziani T, Bluemel C, Schiavina R, Vollmer C, Droll S, Brunocilla E, Mazzarotto R, Buck AK, Fanti S. Impact of 11C-choline PET/CT on clinical decision making in recurrent prostate cancer: results from a retrospective two-centre trial. Eur J Nucl Med Mol Imaging. 2014; 41:2222-31.

42. Öztürk H, Karapolat I.18F-fluorodeoxyglucose PET/CT for detection of disease in patients with prostate-specific antigen relapse following radical treatment of a local-stage prostate cancer. Oncol Lett. 2016; 11:316-22.

43. Fuccio C, Castellucci P, Schiavina R, Santi I, Allegri V, Pettinato V, Boschi S, Martorana G, Al-Nahhas A, Rubello $\mathrm{D}$, Fanti S. Role of 11C-choline PET/CT in the restaging of prostate cancer patients showing a single lesion on bone scintigraphy. Ann Nucl Med. 2010; 24:485-92.

44. Kitajima K, Murphy RC, Nathan MA, Froemming AT, Hagen CE, Takahashi N, Kawashima A. Detection of recurrent prostate cancer after radical prostatectomy: comparison of $11 \mathrm{C}$-choline $\mathrm{PET} / \mathrm{CT}$ with pelvic multiparametric MR imaging with endorectal coil. J Nucl Med. 2014; 55:223-32.
45. Jadvar H, Desai B, Ji L, Conti PS, Dorff TB, Groshen SG, Gross ME, Pinski JK, Quinn DI. Prospective evaluation of $18 \mathrm{~F}-\mathrm{NaF}$ and $18 \mathrm{~F}-\mathrm{FDG}$ PET/CT in detection of occult metastatic disease in biochemical recurrence of prostate cancer. Clin Nucl Med. 2012; 37:637-43.

46. Picchio M, Spinapolice EG, Fallanca F, Crivellaro C, Giovacchini G, Gianolli L, Messa C. [11C]Choline PET/ CT detection of bone metastases in patients with PSA progression after primary treatment for prostate cancer: comparison with bone scintigraphy. Eur J Nucl Med Mol Imaging. 2012; 39:13-26.

47. Husarik DB, Miralbell R, Dubs M, John H, Giger OT, Gelet A, Cservenyàk T, Hany TF. Evaluation of [(18. F]-choline $\mathrm{PET} / \mathrm{CT}$ for staging and restaging of prostate cancer. Eur J Nucl Med Mol Imaging. 2008; 35:253-63.

48. Nanni C, Schiavina R, Brunocilla E, Borghesi M, Ambrosini V, Zanoni L, Gentile G, Vagnoni V, Romagnoli D, Martorana G, Fanti S. 18F-FACBC compared with 11C-choline PET/CT in patients with biochemical relapse after radical prostatectomy: a prospective study in 28 patients. Clin Genitourin Cancer. 2014; 12:106-10.

49. Cimitan M, Bortolus R, Morassut S, Canzonieri V, Garbeglio A, Baresic T, Borsatti E, Drigo A, Trovò MG. [18F] fluorocholine PET/CT imaging for the detection of recurrent prostate cancer at PSA relapse: experience in 100 consecutive patients. Eur J Nucl Med Mol Imaging. 2006; 33:1387-98.

50. Krause BJ, Souvatzoglou M, Tuncel M, Herrmann K, Buck AK, Praus C, Schuster T, Geinitz H, Treiber U, Schwaiger $\mathrm{M}$. The detection rate of $[11 \mathrm{C}]$ choline-PET/CT depends on the serum PSA-value in patients with biochemical recurrence of prostate cancer. Eur J Nucl Med Mol Imaging. 2008; 35:18-23.

51. Castellucci P, Fuccio C, Nanni C, Santi I, Rizzello A, Lodi F, Franceschelli A, Martorana G, Manferrari F, Fanti S. Influence of trigger PSA and PSA kinetics on 11C-Choline $\mathrm{PET} / \mathrm{CT}$ detection rate in patients with biochemical relapse after radical prostatectomy. J Nucl Med. 2009; 50:1394-400.

52. Rinnab L, Mottaghy FM, Simon J, Volkmer BG, de Petriconi R, Hautmann RE, Wittbrodt M, Egghart G, Moeller P, Blumstein N, Reske S, Kuefer R. [11C]Choline PET/CT for targeted salvage lymph node dissection in patients with biochemical recurrence after primary curative therapy for prostate cancer. Preliminary results of a prospective study. Urol Int. 2008; 81:191-7.

53. Fuccio C, Castellucci P, Schiavina R, Guidalotti PL, Gavaruzzi G, Montini GC, Nanni C, Marzola MC, Rubello D, Fanti S. Role of 11C-choline PET/CT in the re-staging of prostate cancer patients with biochemical relapse and negative results at bone scintigraphy. Eur J Radiol. 2012; 81:e893-6.

54. Giovacchini G, Picchio M, Briganti A, Cozzarini C, Scattoni V, Salonia A, Landoni C, Gianolli L, Di Muzio N, Rigatti P, Montorsi F, Messa C. [11C]choline positron emission tomography/computerized tomography to restage prostate cancer cases with biochemical failure after radical 
prostatectomy and no disease evidence on conventional imaging. J Urol. 2010; 184:938-43.

55. Ceci F, Castellucci P, Mamede M, Schiavina R, Rubello D, Fuccio C, Ambrosini V, Boschi S, Martorana G, Fanti S. (11. C-Choline PET/CT in patients with hormoneresistant prostate cancer showing biochemical relapse after radical prostatectomy. Eur J Nucl Med Mol Imaging. 2013; 40:149-55.

56. Fuccio C, Schiavina R, Castellucci P, Rubello D, Martorana G, Celli M, Malizia C, Profitos MB, Marzola MC, Pettinato $\mathrm{V}$, Fanti S. Androgen deprivation therapy influences the uptake of $11 \mathrm{C}$-choline in patients with recurrent prostate cancer: the preliminary results of a sequential PET/CT study. Eur J Nucl Med Mol Imaging. 2011; 38:1985-9.

57. Graute V, Jansen N, Ubleis C, Seitz M, Hartenbach M, Scherr MK, Thieme S, Cumming P, Klanke K, Tiling R, Bartenstein P, Hacker M. Relationship between PSA kinetics and $[18 \mathrm{~F}]$ fluorocholine PET/CT detection rates of recurrence in patients with prostate cancer after total prostatectomy. Eur J Nucl Med Mol Imaging. 2012; 39:271-82.

58. Souvatzoglou M, Krause BJ, Pürschel A, Thamm R, Schuster T, Buck AK, Zimmermann F, Molls M, Schwaiger M, Geinitz H. Influence of (11. C-choline PET/CT on the treatment planning for salvage radiation therapy in patients with biochemical recurrence of prostate cancer. Radiother Oncol. 2011; 99:193-200.
59. Schilling D, Schlemmer HP, Wagner PH, Böttcher P, Merseburger AS, Aschoff P, Bares R, Pfannenberg C, Ganswindt U, Corvin S, Stenzl A. Histological verification of 11C-choline-positron emission/computed tomographypositive lymph nodes in patients with biochemical failure after treatment for localized prostate cancer. BJU Int. 2008; 102:446-451.

60. Richter JA, Rodríguez M, Rioja J, Peñuelas I, MartíCliment J, Garrastachu P, Quincoces G, Zudaire J, GarcíaVelloso MJ. Dual tracer 11C-choline and FDG-PET in the diagnosis of biochemical prostate cancer relapse after radical treatment. Mol Imaging Biol. 2010; 12:210-7.

61. Breeuwsma AJ, Rybalov M, Leliveld AM, Pruim J, de Jong IJ. Correlation of [11C]choline PET-CT with time to treatment and disease-specific survival in men with recurrent prostate cancer after radical prostatectomy. Q J Nucl Med Mol Imaging. 2012; 56:440-6. 